\title{
Contributions of sociodemographic factors to criminal behavior
}

This article was published in the following Dove Press journal:

Psychology Research and Behavior Management

22 June 2016

Number of times this article has been viewed

\author{
Lawrence Mundia \\ Rohani Matzin \\ Salwa Mahalle \\ Malai Hayati Hamid \\ Ratna Suriani Osman \\ Psychological Studies and Human \\ Development Academic Group, \\ Sultan Hassanal Bolkiah Institute \\ of Education, Universiti Brunei \\ Darussalam, Bandar Seri Begawan, \\ Brunei
}

Correspondence: Lawrence Mundia Psychological Studies and Human Development Academic Group, Sultan Hassanal Bolkiah Institute of Education, Universiti Brunei Darussalam, Jalan Tungku Link, Gadong BE I4I0, Bandar Seri Begawan, Brunei

Email lawrence.mundia@ubd.edu.bn

\begin{abstract}
We explored the extent to which prisoner sociodemographic variables (age, education, marital status, employment, and whether their parents were married or not) influenced offending in 64 randomly selected Brunei inmates, comprising both sexes. A quantitative field survey design ideal for the type of participants used in a prison context was employed to investigate the problem. Hierarchical multiple regression analysis with backward elimination identified prisoner marital status and age groups as significantly related to offending. Furthermore, hierarchical multinomial logistic regression analysis with backward elimination indicated that prisoners' age, primary level education, marital status, employment status, and parental marital status as significantly related to stealing offenses with high odds ratios. All 29 nonrecidivists were false negatives and predicted to reoffend upon release. Similarly, all 33 recidivists were projected to reoffend after release. Hierarchical binary logistic regression analysis revealed age groups (24-29 years and 30-35 years), employed prisoner, and primary level education as variables with high likelihood trends for reoffending. The results suggested that prisoner interventions (educational, counseling, and psychotherapy) in Brunei should treat not only antisocial personality, psychopathy, and mental health problems but also sociodemographic factors. The study generated offending patterns, trends, and norms that may inform subsequent investigations on Brunei prisoners.
\end{abstract}

Keywords: crimes, prisoner, sociodemographic, recidivism, interventions, Brunei

\section{Introduction, background, and setting}

There is abundant literature describing the reasons why people offend. Prominent factors attributed often include antisocial personality, ${ }^{1}$ mental health, ${ }^{2}$ and psychopathy. ${ }^{3}$ In this study, we were interested to find out the influence of offender sociodemographic variables such as age, parents' marital status, education, employment, and prisoners' marital state on criminal behavior in the context of Brunei. These sociodemographic variables have not yet been studied extensively in Brunei, and empirical information on them might be useful in profiling career criminals of Brunei and in designing inprison and community-based intervention programs. Due to lack of research, there is, for instance, a general belief in Brunei that criminals were people from a broken family background. Another myth commonly held by many people in Brunei is that stealing or theft offenses were committed mostly by unemployed persons. Part of our goal in this study was to clarify such misconceptions and overgeneralizations. Furthermore, although crime is often committed by and associated with adults in Brunei, there were indications that criminal thinking and activities start much earlier in life when children are still under family and school environments. Indeed, young people or the youth commit a variety of crimes such as stealing, drug abuse, prostitution, 
and murder. However, younger criminals aged 17 years and less were excluded in this study because under Brunei laws minors cannot be imprisoned, though convicted. Instead, they are sent to juvenile correctional centers and Islamic religious rehabilitation institutions to receive educational, counseling, and religious interventions. To determine the number and type of crimes occurring at different age ranges, we arbitrarily divided our sample into four equal-length age groups (18-23 years, 24-29 years, 30-35 years, and 36-40 years). This helped us to know the number and type of crimes committed by younger and older persons.

A review of the relevant literature revealed that mental health was one of the risk factors repeatedly implicated in crimes. ${ }^{4}$ Based on this and other facts, many countries such as Brunei have included mental health promotion in their development goals and plans. Mental health promotion is a primary preventative strategy that can act as a barrier to the onset of mental health-related problems in people. However, to be successful, such a program needs to identify and target appropriate causative factors, risky behaviors, and vulnerable individuals. Some examples of the role of mental health in criminal behavior are presented in the study of Hayes and O'Reilly in which detainees and psychiatric groups were found to have similar deficits in emotional intelligence (EI) and significantly lower EI than the comparison community groups. One of the reasons why criminals have no compassion and remorse for their offenses and victims is because they are low in EI and lack the ability to identify, use, and regulate their emotions wisely. Another trait that Hayes and O'Reilly found in their adolescent/youth prison sample is that they tended to be externalizers rather than internalizers. In the context of this study, an externalizer is an inmate who does not accept responsibility for his/her criminal actions or behaviors but rather rationalizes (finds excuses or makes external attributions) and blames others. They do not look internally or inwardly within themselves to see their causal contributions to problems. In another criminological study ${ }^{5}$ involving the youth, the researchers followed the offending careers of a large number of males from childhood (ages $8-10$ years) to adulthood (48-50 years). The researchers found that by adult age, the participants fell into three categories in terms of criminality: 1) the early starters (ES);2) the late starters (LS); and 3) nonoffenders (NO). According to these researchers, ${ }^{5}$ LS men were more likely than NO men to have been neurotic, truants, or in poor housing at ages 8-10 years. At ages 12-14 years, they tended to be neurotic, and at ages 16-18 years, they had high unemployment and spent time hanging about on the streets. The study ${ }^{5}$ further observed that overall, LS men were more similar to NO men before age 21 years but more similar to ES men by age 32 years. Of course, these findings do not compare directly to the situation in Brunei since there are no previous or ongoing studies of this nature in Brunei, but they provide insightful information about the etiology of crimes.

\section{Theories of offending behavior among the youth and adults}

Recently, researchers ${ }^{6}$ claimed that criminal behavior was influenced by both genes and the environment and their interaction. Their assertions were based on the results of studies of family criminal records, concordance (similarity) studies in identical and fraternal twins, and adoption studies. Evidence from such studies suggests that criminality may be heritable and that it runs in families. For example, in a family in which one of the parents is a criminal, one or more children, if any, might also become a criminal due to the effect of either genes or the presenting environment (or gene-environment interaction). The probability of being a criminal is much higher for a child whose biological parents are both criminals. In the case of identical twins, concordance studies indicate that if one becomes a criminal, the other may also most likely end up being a criminal (even when they are living far apart in different environments).

There is also empirical evidence indicating that social environment, upbringing factors, poverty, disadvantaged neighborhoods, and sex differences contribute to criminality in different ways. A meta-analysis study ${ }^{7}$ identified a number of childhood and adolescent factors that have links with youth antisocial and criminal behaviors. The factors that centered on the child included aggression, attentional problems, motor restlessness, attention seeking, and emotional concerns such as anxiety, self-deprecation, and social alienation. The family predictors included negative parenting strategies such as coerciveness, authoritarian behaviors, lack of child supervision, family violence or interparental conflict, and poor communication. Among the youth, previous research has found that peer influence and conformity were some of the contributing factors to deviant and antisocial behavior. ${ }^{8}$ According to previous research, ${ }^{9}$ the variables that have connections with youth delinquent and criminal behavior were impulsivity and school misconduct. Evidence from other studies ${ }^{6}$ shows that crime runs in families. For example, one investigation ${ }^{10}$ found that the majority of criminal children had a criminal father. In a later study, ${ }^{11}$ it was found that $53 \%$ of men with a criminal conviction also had 
a convicted family member. Moreover, other researchers ${ }^{12}$ found that parents with criminal and violent behavior caused antisocial behavior in their offspring through the parents' problematic parenting styles such as inconsistent rule enforcement, marital arguments, angry interactions with children, and disrupted families.

At the family/relationships level, several factors are suspected of leading people to commit crime. They include family factors such as interpersonal hostility; ${ }^{13}$ authoritarian or coercive parenting style, child abuse, interparental conflict or domestic violence, and poor family communication; ${ }^{7}$ large family size; low parental education; and family offending history ${ }^{14}$ as well as peer group pressure and bullying. ${ }^{15}$

\section{Criminal and noncriminal psychological research on Brunei Darussalam}

A small amount of psychological research has been conducted on crimes in Brunei, but much of it does not appear in books or journals. In view of this, published crime research on Brunei is still meager and sparse. There are many reasons why psychological research is still scant in Brunei. Brunei people are, by nature, extremely shy and anxious to voluntarily discuss their personal problems with other people such as counselors or psychologists. In addition, the use of western research instruments written in advanced English is still not feasible due to language problems as Bahasa Melayu is the mother tongue and predominant language. ${ }^{16,17}$ Despite these problems, a few crime-related studies have been conducted on Brunei. For instance, one study ${ }^{18}$ examined the status of counseling in Brunei prisons. The other recent studies relevant to criminology investigated youth and adult crimes in Brune $i^{19}$ and mental health issues that often lead teachers to commit criminal offenses in schools. ${ }^{20,21}$ However, these last two studies were not on prisoners. Most of the psychological research that has been conducted in Brunei has focused largely on noncriminal student and community populations particularly on disabilities, health, and other social issues. These studies were limited in that they were not directly related to crimes in Brunei, the concern of the current research. However, the importance of these psychological studies is that they demonstrate ongoing efforts being made to conduct research of a psychological nature on Brunei to develop norms for future reference. In addition, this body of research has served to fill in and narrow some of the knowledge gaps. For example, the findings of some psychological studies conducted on school children might help to predict the behavior of these children in adulthood.

\section{Objectives of the study}

Crime still has a low prevalence rate in Brunei and is one of the many underresearched problems in the Sultanate. The fact that not much is researched and published on crime issues in Brunei does not necessarily suggest or imply that the country is secure and safe. There are a few individuals who constitute a danger to society. Furthermore, that this study was funded by a government institution was, in itself, clear evidence that the government wanted to do more to prevent and contain the crime rate in the small peaceful Muslim nation. Above all, the recent introduction and implementation of the Sharia law and penal code in Brunei, which heavily punishes offenses such as stealing, adultery, rape, and drug use or trafficking, was partly intended to contain the crime rate in the country. Based on these developments, the purpose of this study was therefore to seek more information about the characteristics of the perpetrators of crimes and the possible sociodemographic factors influencing criminal behavior and provide information to policy makers that could inform appropriate interventions. This psychological study aims to contribute new knowledge to an understanding of the relationship between crime and society in the Sultanate of Brunei, Southeast Asia. In addition, the current relatively small-scale study represents a preliminary step toward greater clarification of the factors driving criminal behavior in Brunei prisoners that would be of interest in a future large-scale research work involving all prisoners in Brunei. Our three main and specific research objectives were as follows:

- To determine the relationship between offending and selected sociodemographic variables (age, education, employment, marital status, and parents' marital state).

- To determine the sociodemographic factors that strongly influence stealing, the biggest crime in Brunei Darussalam.

- To determine the probability of reoffending among the first-time convicts based on the sociodemographic variables investigated in this study.

\section{Methods}

We briefly explain later under separate subheadings the design, sample, instruments, procedures, and data analyses strategies employed in this study.

\section{Design}

We investigated the problem using the quantitative field survey approach. This strategy was considered to be faster and effective than other survey techniques (eg, telephone, online, postal, and longitudinal) as we could get enough usable returns quickly. 


\section{Sample}

The two prisons in Bandar Seri Begawan, Brunei Darussalam, had $>200$ inmates at the time of collecting data for this study. Of these, 64 (32\%) were chosen using the simple random selection procedure for participation in the study. The four inclusion criteria were: 1) being male or female by sex; 2) incarcerated for the first time or more than once; 3) Brunei nationality/citizenship or permanent resident status; and 4) voluntarily willing to participate in the study. There were no other inclusion and exclusion criteria. The majority of these convicts were males. Other demographic characteristics of the obtained sample are displayed in Table 1.

\section{Instruments}

Data for this study came from a qualitative interview schedule. The interview schedule (with probes) that collected demographical information was constructed by the researchers based on the review of the relevant literature. The biodata collected via interviews included (among others) a wide range of categorical variables concerning the participants' sex, age, education, marital status, employment details, type of crime committed, number of times the same crime was repeatedly committed, and the reasons for committing the crime(s). The instrument was initially written in simple English but later translated into Bahasa Melayu, the main and official language of Brunei and the language in which it was administered to inmates. The forward translation was done by two of the researchers for this study (both counselors) who were bilinguals and spoke both English and their native Bahasa Melayu. Two other bilingual researchers for this study (both psychologists) who also spoke Bahasa Melayu as a first language served as back translators

Table I Participants' demographic information ( $N=64)$

\begin{tabular}{llll}
\hline Groups & & Frequency & Percentage \\
\hline Sex & Males & 58 & 91 \\
Education level & Females & 6 & 9 \\
& University & 0 & 0 \\
& College & 1 & 2 \\
& Secondary & 49 & 77 \\
& Primary & 14 & 21 \\
Marital status & Married & 23 & 36 \\
& Divorced & 0 & 0 \\
& Widowed & 7 & 11 \\
\multirow{5}{*}{ Nationality } & Single & 34 & 53 \\
& Citizens & 56 & 87 \\
& Permanent residents & 8 & 13 \\
& & Mean & Standard \\
Age (years) & All & & deviation \\
& Males & 29.421 & 6.868 \\
& Females & 29.145 & 6.738 \\
& & 29.000 & 6.164 \\
\hline
\end{tabular}

and confirmed the clarity of expression and conceptual equivalence of the items in the translated Malay version to those in the original English edition, thereby attesting to the instrument's triangulation validity. In addition, the study had adequate ecological validity as the data were collected via individual prisoner interviews in the participants' usual jail environment by two trained prison officials who regularly interacted with the respondents on a daily basis. The inter-rater agreement reliability for the two instrument administrators was $91 \%$.

\section{Procedures}

Permission and approval to conduct the study were obtained from the Universiti Brunei Darussalam (UBD), Ethics Commitee and the Prison Department Administration in the Government of Brunei Darussalam. All relevant ethical conditions for being involved in the study, such as voluntary participation, privacy, anonymity, confidentiality, and protection from harm (both physical and psychological) were explained to the research participants verbally in Bahasa Melayu language. Participants gave their verbal consent to be included and this met with the requirements of the ethics committee. All the instrument translators and administrators were Brunei citizens and native speakers of Bahasa Melayu language.

\section{Data analysis}

The categorical demographical items in the interview code were used as grouping variables, and data derived from them were analyzed quantitatively using descriptive statistics (frequencies, percentages, mean, and standard deviation) and by inferential statistics (hierarchical multiple regression analysis with backward elimination, hierarchical multinomial logistic regression analysis, and hierarchical binary logistic regression analysis). All the statistical analyses were performed using SPSS Version 22 (using functions such as frequency, descriptive statistics, cross-tabulations, and regression).

\section{Results}

The major findings of this study solely based on the sample are presented mainly in the form of tables per objectives of the investigation.

\section{Major crimes by frequency, percentage, and rank}

Overall, 12 types of crimes were committed by participants in the study (Table 2). Burglary or stealing was the most common and main felony committed (representing $38 \%$ or $59 \%$ of all the crimes combined). This was followed by drug and sex offenses, respectively. The chi-square and phi coefficients could not be 
Table 2 Types of crime, number, and percentage $(\mathrm{N}=64)$

\begin{tabular}{lll}
\hline Types of crime & Frequency & Percentage \\
\hline Drug offences (abusing and trafficking) & 7 & $1 \mathrm{I}$ \\
Stealing/burglary & 38 & 59 \\
Burning cars or property/arson & $\mathrm{I}$ & 2 \\
Violent/aggressive (fighting, injuring, & 4 & 6 \\
attempted murder) & & \\
Sex offences (rape, incest, adultery) & 6 & 9 \\
Conning & 2 & 3 \\
Smuggling goods (eg, cigarettes, alcohol) & 1 & 2 \\
Growing drug plants & 1 & 2 \\
Prostitution and female trafficking including & 1 & 2 \\
abuse of foreign female domestic workers & & \\
Forgery (eg, using other peoples' & 1 & 2 \\
documents) & & \\
Gambling & 1 & 2 \\
Corruption offenses & I & 2 \\
\hline
\end{tabular}

calculated on the data in Table 2 (to show the significance of the relationship between column and row variables) because of the presence of many cells with small frequencies $<5$ in magnitude. In addition, the trend of crimes presented in Table 2 could not be compared to previous patterns as such evidence was not available due to lack of research.

\section{Crimes by parents' marital status}

The parents of our prison sample had diverse marital status (ranging from married, divorced, and separated, to single) as shown in Table 3. However, most of the crimes in this study were committed by inmates with married parents. Convicts with divorced and single parents committed the second and third highest numbers of crimes, respectively. The relationship between the row and column variables in Table 3 was not computed using the chi-square and phi statistics because the data were very sparse with many empty cells and several cells containing small frequency values $<5$ in size. The prisoners' parents categorized as "divorced, separated, and single" needed to be combined and recoded to form a new variable called "unmarried parents". Despite this, the data in Table 3 captured a pattern or trend of offending behavior based on the participants' family background.

\section{Crimes by age-groups}

Our sample (age range 18-40 years) was by chance arbitrarily dividable into four natural and equal-length age intervals presented in Table 4, which clearly shows that members of all four age groups (younger and older inmates) committed crimes in this study. Participants aged 24-29 years committed the highest number of crimes followed by those in the 36-40 years age group. However, the younger prisoners (age range 18-29 years) committed more crimes compared to their older counterparts aged 30-40 years. An analysis of the type of crimes perpetrated revealed that both groups (young and old prisoners) were high on stealing (theft or housebreaking; Table 4). Differences on other types of crimes emerged. For example, older offenders were more involved in drug-related crimes than younger ones. On the other hand, younger prisoners were more into violent/

Table 3 Types of crime (n) by parents' marital status $(\mathrm{N}=64)$

\begin{tabular}{|c|c|c|c|c|c|}
\hline \multirow[t]{2}{*}{ Crime } & \multicolumn{4}{|c|}{ Parents' marital status } & \multirow{2}{*}{$\begin{array}{l}\text { Total } \\
\text { (\%) }\end{array}$} \\
\hline & Married & Divorced & Separated & Single & \\
\hline Drug offences & 2 & 2 & 0 & 3 & $\begin{array}{l}7 \\
(11 \%)\end{array}$ \\
\hline Stealing/burglary & 20 & 9 & 1 & 8 & $\begin{array}{l}38 \\
(59 \%)\end{array}$ \\
\hline Arson & 0 & 0 & 1 & 0 & I $(2 \%)$ \\
\hline Aggression & 3 & 1 & 0 & 0 & $4(6 \%)$ \\
\hline Sex offenses & 5 & 0 & 0 & I & $6(9 \%)$ \\
\hline Conning & 1 & 1 & 0 & 0 & $2(3 \%)$ \\
\hline Smuggling & 1 & 0 & 0 & 0 & I (2\%) \\
\hline Growing drug plants & 1 & 0 & 0 & 0 & I $(2 \%)$ \\
\hline $\begin{array}{l}\text { Prostitution and } \\
\text { female trafficking } \\
\text { including abuse } \\
\text { of foreign female } \\
\text { domestic workers }\end{array}$ & 1 & 0 & 0 & 0 & I (2\%) \\
\hline Forgery & 1 & 0 & 0 & 0 & $\mathrm{I}(2 \%)$ \\
\hline Gambling & 1 & 0 & 0 & 0 & I (2\%) \\
\hline Corruption offenses & 0 & 1 & 0 & 0 & I $(2 \%)$ \\
\hline Total (\%) & $36(56 \%)$ & $14(22 \%)$ & $2(3 \%)$ & $\begin{array}{l}12 \\
(19 \%)\end{array}$ & $\begin{array}{l}64 \\
(100 \%)\end{array}$ \\
\hline
\end{tabular}

Table 4 Types of crime $(\mathrm{n})$ by age groups $(\mathrm{N}=64)$

\begin{tabular}{|c|c|c|c|c|c|}
\hline Types of crime & $18-23$ & 24-29 & $30-35$ & $36-40$ & Total (\%) \\
\hline Drug offences & 0 & I & 2 & 4 & $7(11 \%)$ \\
\hline Stealing/burglary & 10 & 13 & 8 & 7 & 38 (59\%) \\
\hline Burning cars/arson & 0 & I & 0 & 0 & I (2\%) \\
\hline $\begin{array}{l}\text { Violent/aggressive } \\
\text { (fighting, injuring, } \\
\text { attempted murder) }\end{array}$ & I & 2 & I & 0 & $4(6 \%)$ \\
\hline $\begin{array}{l}\text { Sex offences (rape, } \\
\text { incest, adultery) }\end{array}$ & 2 & 0 & 1 & 3 & $6(9 \%)$ \\
\hline Conning & 0 & 0 & I & I & $2(3 \%)$ \\
\hline $\begin{array}{l}\text { Smuggling goods } \\
\text { (eg, cigarettes) }\end{array}$ & 0 & 0 & 1 & 0 & I (2\%) \\
\hline Growing drug plants & 0 & I & 0 & 0 & I (2\%) \\
\hline $\begin{array}{l}\text { Prostitution and } \\
\text { female trafficking } \\
\text { including abuse } \\
\text { of foreign female } \\
\text { domestic workers }\end{array}$ & 0 & 0 & 0 & I & I (2\%) \\
\hline $\begin{array}{l}\text { Forgery (eg, using } \\
\text { other peoples' } \\
\text { documents) }\end{array}$ & 0 & 0 & 0 & I & I (2\%) \\
\hline Gambling & 0 & 0 & 0 & I & I (2\%) \\
\hline Corruption offenses & 0 & I & 0 & 0 & I (2\%) \\
\hline Total (\%) & $13(20 \%)$ & $19(30 \%)$ & $14(22 \%)$ & $18(28 \%)$ & $64(100 \%)$ \\
\hline
\end{tabular}


aggressive offenses such as fighting than older inmates. The most active sexual predators in the study sample were those convicts aged 18-23 years and 36-40 years. The chi-square and phi coefficients were not obtained on the data in Table 4 to determine the strength of the relationship between the row and column variables because there were far too many empty cells and cells with small frequency values $<5$.

\section{Crimes by prisoners' marital status}

After the prisoners' marital status was dichotomized into two categories (married and unmarried), we found that the two groups had almost an equal amount of crime rates. However, married inmates ( 20 persons) stole more than their unmarried counterparts (18 people). In addition, aggression and sex offenses were slightly higher in unmarried prisoners than in married convicts. The strength of relationship between the variables and the significance of the differences between the cells could not be determined because of the presence of numerous empty cells and cells with small frequencies in the cross-tabulation frequency table.

\section{Crimes by prisoners' employment status and recidivism}

Contrary to our expectations, the employed prisoners outnumbered their unemployed counterparts. This overrepresentation was surprising considering that the majority of crimes committed (eg, stealing) were of an economic nature. With regard to recidivism, the number of repeat offenders was slightly higher than that of nonrepeat offenders. Drugs, theft, sex, and conning offenses had more repeat offenders in the sample than other types of crimes. Again, no chi-square and phi coefficients were computed on the employment and recidivism data due to the presence of numerous empty cells and cells with small frequencies.

\section{Relationship between selected sociodemographic prisoner variables and offending using backward elimination multiple regression analysis}

As already explained earlier, we were not able to determine the relationship between a set of prisoner sociodemographic variables and offending using the chi-square and phi statistics to address our first research objective. To explore this relationship meaningfully and effectively, we used the hierarchical multiple regression analysis with backward elimination, a more robust procedure. As stated above, the sociodemographic variables of interest in our study were prisoners' age, education, marital status, employment, and whether the participants' parents were married or not (as explanatory or independent variables [IVs]) versus the type of crimes committed (as a response or dependent variable [DV]). We employed both the unstandardized $(B)$ and standardized Beta regression coefficients as a basis for identifying IVs with stronger influence on the DV (offending). The $B$ and Beta coefficients showed the estimated change in the response (DV) variable associated with a unit change in the corresponding explanatory (IV) variable, conditional on the other explanatory variables remaining constant. Table 5 shows the results we obtained from the five-step backward elimination multiple regression analysis. In this table, Model 5 shows that prisoner marital status $(\underline{P}<0.05)$ and age groups $(P<0.01)$ were the most strongly related variables to offending according to our Brunei prison sample. The main changes that occurred to the $R, R^{2}$, and $F$ statistics at each of the five stages or models are summarized and presented in Table 6.

\section{Relationship between selected prisoner variables and offending using multinomial logistic regression}

We considered the variables in Table 5 to have had practical significance for this study. However, because both the IVs and DV in Table 5 were categorical variables, we decided to further investigate the relationship using hierarchical multinomial logistic regression analysis. In particular, we wanted to identify the IVs that were most related to stealing, the major crime in this study as indicated in Table 2. To achieve our second research objective in a multinomial logistic regression fashion, we used log-odds parameters. The estimated regression coefficients in a logistic regression model give the estimated change in the log-odds corresponding to a unit change in the corresponding explanatory variable when other IVs are held constant. ${ }^{22}$

\section{Relationship between prisoner sociodemographic variables and stealing offenses}

According to Table 7, the six prisoner sociodemographic variables that were found to have big influence on theft crimes were age group 30-35 and 36-40 years, primary level education, married prisoner, employed prisoner, and married parental background. Age group 24-29 years neared significance level and showed a potential trend or pattern for being an influential variable with regard to stealing. Both age group $30-35$ and 36-40 years were significantly related variables to stealing, but convicts aged 30-35 years had higher likelihood for stealing (odds ratio $[\mathrm{OR}]=0.033$, standard error $[\mathrm{SE}]$ 
Table 5 Hierarchical multiple regression analysis with backward elimination on crimes $^{\mathrm{a}}$

\begin{tabular}{|c|c|c|c|c|c|}
\hline Model/variables & B & SE & $\boldsymbol{\beta}$ & $\boldsymbol{t}$ & $P$ \\
\hline \multicolumn{6}{|l|}{ Model I } \\
\hline Educational level & 0.810 & 0.737 & 0.355 & 1.098 & 0.278 \\
\hline Prisoner marital status & 0.762 & 0.696 & 0.295 & 1.094 & 0.280 \\
\hline Employment & 0.449 & 1.131 & 0.121 & 0.397 & 0.693 \\
\hline Recidivism & -0.857 & 0.772 & -0.151 & -1.109 & 0.273 \\
\hline Parents marital status & -0.708 & 0.702 & -0.262 & -1.009 & 0.318 \\
\hline Age groups & 0.643 & 0.316 & 0.423 & 2.033 & $0.048^{*}$ \\
\hline \multicolumn{6}{|l|}{ Model 2} \\
\hline Educational level & 0.916 & 0.681 & 0.401 & 1.345 & 0.185 \\
\hline Prisoner marital status & 0.868 & 0.637 & 0.336 & 1.364 & 0.179 \\
\hline Recidivism & -0.836 & 0.764 & -0.147 & -1.095 & 0.279 \\
\hline Parents marital status & -0.677 & 0.691 & -0.251 & -0.979 & 0.332 \\
\hline Age groups & 0.671 & 0.306 & $0.44 I$ & 2.193 & $0.033^{*}$ \\
\hline \multicolumn{6}{|l|}{ Model 3} \\
\hline Educational level & 0.628 & 0.614 & 0.275 & 1.022 & 0.312 \\
\hline Prisoner marital status & 0.731 & 0.621 & 0.283 & 1.178 & 0.245 \\
\hline Recidivism & -1.070 & 0.725 & -0.189 & -1.476 & 0.146 \\
\hline Age groups & 0.624 & 0.302 & 0.410 & 2.066 & $0.044^{*}$ \\
\hline \multicolumn{6}{|l|}{ Model 4} \\
\hline Prisoner marital status & 1.173 & 0.446 & 0.454 & 2.632 & $0.011 * *$ \\
\hline Recidivism & -1.112 & 0.724 & -0.196 & -1.534 & 0.131 \\
\hline Age groups & 0.783 & 0.259 & 0.514 & 3.023 & $0.004 * *$ \\
\hline \multicolumn{6}{|l|}{ Model 5} \\
\hline Prisoner marital status & 0.961 & 0.429 & 0.372 & 2.238 & $0.030 *$ \\
\hline Age groups & 0.677 & 0.253 & 0.445 & 2.677 & $0.010 * *$ \\
\hline
\end{tabular}

Notes: alinear regression through the origin. $* P<0.05 ; * * P<0.01$ (both two-tailed). Abbreviation: SE, standard error.

Table 6 Model summary of the backward elimination multiple regression analysis

\begin{tabular}{lllllllllll}
\hline Model & $R$ & $R^{2}$ & Adj $\boldsymbol{R}^{2}$ & SE est & \multicolumn{6}{c}{ Change statistics } \\
\cline { 5 - 10 } & & & & & $\Delta \boldsymbol{R}^{2}$ & $\Delta \boldsymbol{F}$ & $\mathbf{d f}_{1}$ & $\mathbf{d f}_{2}$ & $\boldsymbol{P}$ \\
\hline $\mathrm{I}$ & 0.808 & 0.653 & 0.608 & 2.625 & 0.653 & 14.718 & 6 & 47 & $0.000^{*}$ \\
2 & 0.807 & 0.651 & 0.615 & 2.602 & -0.001 & 0.157 & $\mathrm{I}$ & 47 & 0.693 \\
3 & 0.803 & 0.645 & 0.616 & 2.601 & -0.007 & 0.959 & $\mathrm{I}$ & 48 & 0.332 \\
4 & 0.798 & 0.637 & 0.615 & 2.602 & -0.008 & 1.045 & $\mathrm{I}$ & 49 & 0.312 \\
5 & 0.787 & 0.620 & 0.605 & 2.637 & -0.017 & 2.354 & $\mathrm{I}$ & 50 & $0.13 \mathrm{I}$ \\
\hline
\end{tabular}

Note: $* P<0.01$ (two-tailed).

Abbreviations: Adj, adjusted; SE, standard error; est, estimate; df, degrees of freedom.
$=0.983,95 \%$ confidence interval $[\mathrm{CI}]$ for $\mathrm{OR}=0.005-0.229$ ) compared to those aged 36-40 years $(\mathrm{OR}=0.006, \mathrm{SE}=1.077$, $95 \% \mathrm{CI}=0.001-0.051)$. Prisoners who had only primary school education were 17 times likely to steal than those with higher education $(\mathrm{OR}=17.171, \mathrm{SE}=1.212,95 \% \mathrm{CI}=1.597-184.572)$. Following somewhat similar interpretations, we noticed that three variables in Table 7 (married prisoners, employed prisoners, and prisoners with married parents) had exceptionally high odds for stealing $(26,34$, and 9 , respectively) than others. These three variables increased the probability of committing theft crimes in our sample, while age group variables showed the lowest odds for stealing. Of all the variables presented in Table 7, employed prisoner was most significantly related to stealing $(P<0.001)$ and had the highest odds for stealing compared to other variables $(\mathrm{OR}=34.006, \mathrm{SE}=0.754,95 \%$ $\mathrm{CI}=7.752-149.165)$.

\section{Predicting reoffending using selected prisoner sociodemographic variables}

Offenders are put in jail to prevent them from hurting or harming people continuously in the community and society. Since the majority of the prisoners do not serve a life sentence, efforts are made through education, counseling, psychotherapy, and vocational training to rehabilitate them before release and re-integration in the society. The problem here is that not all prisoners reform and change adequately or for a long time. A number of ex-convicts relapse and begin reoffending, behavior that leads them to re-conviction. In this way, they pose a real danger to security and safety in the community and society once again. The third broad objective of this study was to predict and determine the number and percentage of participants who were likely to be repeat offenders or recidivists upon release. To address this objective, we used the hierarchical binary logistic regression analysis method that requires a dichotomous DV. We chose recidivism (which was coded as 0 for a nonrepeat offender and 1 for a repeat offender) as our DV. The IVs were

Table 7 Hierarchical multinomial logistic regression analysis on stealing ${ }^{a}$

\begin{tabular}{|c|c|c|c|c|c|c|c|c|}
\hline \multirow[t]{2}{*}{ Variable } & \multirow[t]{2}{*}{ B } & \multirow[t]{2}{*}{ SE } & \multirow[t]{2}{*}{ Wald's $\chi^{2}$} & \multirow[t]{2}{*}{ df } & \multirow[t]{2}{*}{$P$} & \multirow[t]{2}{*}{ OR } & \multicolumn{2}{|c|}{$95 \% \mathrm{Cl}$ for OR } \\
\hline & & & & & & & Lower & Upper \\
\hline Aged 24-29 years & -1.398 & 0.752 & 3.456 & 1 & 0.063 & 0.247 & 0.057 & 1.079 \\
\hline Aged $30-35$ years & -3.399 & 0.983 & 11.951 & 1 & $0.001 * *$ & 0.033 & 0.005 & 0.229 \\
\hline Aged $36-40$ years & -5.087 & 1.077 & 22.327 & 1 & $0.000 * * *$ & 0.006 & 0.001 & 0.051 \\
\hline Primary level education & 2.843 & 1.212 & 5.506 & 1 & $0.019 *$ & 17.171 & 1.597 & 184.572 \\
\hline Married prisoner & 3.269 & 0.728 & 20.137 & 1 & $0.000 * * *$ & 26.278 & 6.303 & 109.556 \\
\hline Employed prisoner & 3.527 & 0.754 & 21.854 & 1 & $0.000 * * *$ & 34.006 & 7.752 & 149.165 \\
\hline Married parents & 2.227 & 0.643 & 11.985 & 1 & $0.00 I^{* *}$ & 9.276 & 2.628 & 32.734 \\
\hline
\end{tabular}

Notes: ${ }^{a}{ }^{2}=0.967$ (Cox and Snell); 0.974 (Nagelkerke); 0.689 (McFadden). Model $\chi^{2}(23 \mathrm{I})=34.533$. $* P<0.05$ (two-tailed);

$* * P<0.01$ (two-tailed); $* * * P<0.001$ (two-tailed).

Abbreviations: SE, standard error; df, degrees of freedom; OR, odds ratio; $\mathrm{Cl}$, confidence interval. 
the same sociodemographic variables used in the hierarchical multinomial logistic regression analysis described earlier. In addition, we used the backward elimination technique to enter and retain the terms in the binary logistic regression model. The backward elimination method starts with a model containing all the explanatory variables and removes variables one by one, at each stage choosing the variable for exclusion as the one leading to the smallest decrease in the regression sum of squares. ${ }^{22,23}$ The default significance level required by $\mathrm{SPSS}^{22}$ and $\mathrm{SAS}^{23}$ for variables to enter and stay in the regression equation is a less stringent criteria $P=0.15$. This study used $P=0.05$ for entry and $P=0.10$ for removal. Each stage or step is known as a model. Table 8 shows all the IVs that were initially entered into the five-step hierarchical binary logistic regression model. Clearly, not all the variables at each step were informative in predicting repeat offending/recidivism. In fact, none of the variables in Table 8 was significantly related with reoffending. However, we were interested here in practical, rather than statistical, significance. Of importance to us were sociodemographic variables that were associated with a pattern or trend of high odds for reconviction. In Model 1, for example, inmates aged 30-35 years had higher odds for reoffending than those aged 24-29 years $(\mathrm{OR}=1.278,95 \% \mathrm{CI}=0.236-6.924$; Table 8$)$. Similarly (in Model 1 of Table 8), convicts with primary level education were three times likely to reoffend than other prisoners $(\mathrm{OR}=3.447, \mathrm{SE}=0.796,95 \% \mathrm{CI}=0.725-16.392)$. Primary level education persisted as the variable with the highest odds for reoffending throughout the five binary logistic models (OR =2.667, 95\% CI =0.707-10.052; Table 8, Model 5).

The hierarchical binary logistic regression analysis identified the cases in our sample who were likely to relapse and reoffend upon release. Of the $64(100 \%)$ participants, two respondents were excluded from analysis due to missing values. The remaining 62 (97\%) cases consisted of $29(47 \%)$ nonrecidivists coded 0 and $33(53 \%)$ recidivists coded 1 . All the 29 nonrecidivists were found to be false negatives in this study and projected to reoffend after release. Similarly, all the 33 recidivists in this study were also predicted to reoffend upon release. We thus had no false positives in this study.

\section{Discussion}

We obtained a number of wide-ranging findings, some of which require further interpretation and clarification here. These are discussed below under separate subheadings.

\section{Crimes by parents' marital status}

It is a worrying phenomenon to note from the results of this study that convicts with married parents committed more crimes than those with other categories of parents. In the absence of qualitative research with interview probes, it is difficult and challenging here to understand the factors behind this finding. What this finding suggests is that it is not the type of marital status that matters most in bringing up good lawabiding children but rather the parenting skills/strategies used. The importance of proper parenting is adequately captured in an old Malay adage which says: "if you want to bend a bamboo, start with the shoot". Once you miss the childhood developmental stage, you have probably lost the golden chance or opportunity to significantly influence and shape the child's personality and behavior. We suspect that most of the defective and dysfunctional married and intact families in this study were probably those who used the laissez-faire (indifferent or do not care attitude) and authoritarian (coercive or autocratic) parenting styles. Research by developmental psychologists has repeatedly implicated coercive home environments as breeding grounds for chronic aggression and delinquency. ${ }^{7,24}$ The inability or failure of the most ideal family arrangement (married biological parents living together with offspring) to raise well-behaved children and prevent them from committing crimes is a source of great concern to society as well as

Table 8 Hierarchical binary logistic regression analysis with backward elimination on recidivism

\begin{tabular}{|c|c|c|c|c|c|c|c|c|c|}
\hline \multirow[t]{2}{*}{ Model } & \multirow[t]{2}{*}{ Variables } & \multirow[t]{2}{*}{ B } & \multirow[t]{2}{*}{ SE } & \multirow[t]{2}{*}{ Wald's $\chi^{2}$} & \multirow[t]{2}{*}{ df } & \multirow[t]{2}{*}{$P$} & \multirow[t]{2}{*}{ OR } & \multicolumn{2}{|c|}{$95 \% \mathrm{Cl}$ for OR } \\
\hline & & & & & & & & Lower & Upper \\
\hline \multirow[t]{7}{*}{ Step $I^{a}$} & Aged 18-23 years & -0.731 & 0.814 & 0.806 & I & 0.369 & $0.48 \mathrm{I}$ & 0.098 & 2.375 \\
\hline & Aged 24-29 years & 0.042 & 0.707 & 0.004 & I & 0.952 & 1.043 & 0.261 & 4.169 \\
\hline & Aged $30-35$ years & 0.245 & 0.862 & 0.081 & I & 0.776 & 1.278 & 0.236 & 6.924 \\
\hline & Primary level education & 1.238 & 0.796 & 2.420 & I & 0.120 & 3.447 & 0.725 & 16.392 \\
\hline & Married prisoner & -0.302 & 0.600 & 0.254 & I & 0.614 & 0.739 & 0.228 & 2.394 \\
\hline & Employed prisoner & 0.653 & 0.665 & 0.963 & I & 0.326 & 1.921 & 0.521 & 7.078 \\
\hline & Married parents & -0.836 & 0.569 & 2.158 & I & 0.142 & 0.434 & 0.142 & 1.322 \\
\hline Step $5^{b}$ & Primary level education & 0.981 & 0.677 & 2.099 & I & 0.147 & 2.667 & 0.707 & 10.052 \\
\hline
\end{tabular}

Notes: a Model I: $R^{2}=0.123$ (Cox and Snell); 0.165 (Nagelkerke). ${ }^{\text {bModel }} \chi^{2}(\mathrm{I})=6.979$. Model 5: $R^{2}=0.044$ (Cox and Snell); 0.058 (Nagelkerke). Model $\chi^{2}(\mathrm{I})=2.358$. Abbreviations: $\mathrm{SE}$, standard error; df, degrees of freedom; $\mathrm{OR}$, odds ratio; $\mathrm{Cl}$, confidence interval. 
researchers. To understand the problem better, the ongoing and future qualitative research should examine the developmental stage (especially adolescence) at which most Brunei children start becoming criminals and the factors that maintain their antisocial behaviors such as peer group influences and pressures. Previous research also looked at the effectiveness of the available juvenile rehabilitation programs, ${ }^{15}$ and Brunei might wish to consider doing the same. In addition, conducting separate focus-group interviews with married parents and other categories of parents may, in particular, be informative, insightful, and beneficial to inform solutions on youth crimes. Interventions in effective parenting skills (eg, management of bullying and defiant behavior in children) are highly recommended. Such interventions could be provided by psychologists, counselors, sociologists, and social workers. Parents could also benefit from religious institutions on appropriate values to be instilled in their children.

\section{Crimes by age groups}

The majority of younger prisoners were involved in stealing/ housebreaking offenses, whereas adult inmates covered a much wider range of crimes, the major ones being theft, drug, and sex offenses. Based on these findings, it is quite clear that there is a major need to provide psychological/counseling services and other interventions to both the younger and the older prisoners. A number of effective intervention programs for youth criminals that may be suitable for use in Brunei have been devised ${ }^{25}$ and reviewed. ${ }^{26}$ In addition, a variant of cognitive behavior counseling known as self-instructional therapy might also be suitable for youth criminals of Brunei. ${ }^{27}$

\section{Crimes by younger and older inmates}

With both groups committing almost an equal number of crimes, we suggest that attention, priority, and energy be directed toward preventing the onset of criminality and known risk factors associated with childhood antisocial behaviors such as the influence of delinquent peers. ${ }^{28}$ Children who are exposed to multiple behavioral risks for criminality are disproportionately likely to become serious persistent offenders. It is this group of children who need to be targeted. According to previous research, ${ }^{26}$ the strategies that were successful in US and UK included: 1) early home visits and preschool education programs; 2) parenting programs; 3) family-school initiatives; 4) anti-bullying strategies in schools; and 5) counseling or psychotherapy (both individual and group). Another previous study ${ }^{25}$ provides accounts of 30 such programs operating in the UK, such as the "Sure Start" and "On Track" initiatives. Early intervention at the preschool or initial school might be necessary and effective. The best known preschool intervention is "Operation Headstart", which was introduced in America in the 1960s and attempted to accelerate cognitive development in children from high-risk families before their entry to school.

\section{Relationship between prisoner sociodemographic variables versus offending, stealing, and reoffending}

This study identified parental marital status and the child's educational level as the two main factors influencing offending and reoffending. These and other factors need to be incorporated and addressed in all educational, counseling, and psychotherapy interventions involving prisoners, parents, and vulnerable children at risk of becoming criminals. Of particular interest in this study are cases who were predicted to maintain the status quo with regard to offending. The repeat offenders are hard-core criminals who are resistant to change, while the false negatives show a trend for becoming persistent offenders. Altogether, these two types of people totaled 62 $(97 \%)$ in this study and would be dangerous individuals when released back to the community or society, as they will try to perpetrate their criminal careers. This is a large number of people who need intensive rehabilitation both in prison before release and in community after release to reduce relapse incidences. There were no false positives in this study.

\section{Conclusion}

There was a relationship between offending and two prisoner variables (educational level and parents' marital status). The main crime committed by the convicts was stealing, and it was influenced by a number of factors such as age, education, marital status of the prisoner, employment, and marital status of the parents. The two broad and most relevant variables in predicting reoffending or recidivism were prisoner educational level and parents' marital status. Contingency plans and measures need to be put in place to ensure that security and safety in the county are not threatened by convicts who were projected to be multiple offenders, when released back to community and society. This could be done via in-prison and community-based educational interventions, counseling, and psychotherapy. This research needs to be replicated using qualitative methods to gain more understanding of the problems and the solutions.

\section{Limitations of the study}

This study had three main limitations. First, a qualitative component was not included to complement or supplement findings from the quantitative survey. Second, due to lack 
of time and research assistants, data from other institutions that deal with criminals (eg, Bureau for Narcotics and Nur Hedayah) were not included in this study. This would have increased the present moderate-sized sample. Third, social desirability may have undermined the effectiveness of this research but every effort was made to control and reduce it (eg, by training and allowing prison personnel rather than the researchers to administer the instrument and collect the data). Despite these shortcomings, the present prison-based study has high practical significance and might be of value to both the local Brunei society and the international community elsewhere in the world.

\section{Acknowledgment}

This study was supported by Grant No UBD/PNC2/2/ RG/1(232) dated May 23, 2012 from the Centre for Advanced Research, Universiti Brunei Darussalam, Brunei.

\section{Disclosure}

The authors report no conflicts of interest in this work.

\section{References}

1. Eysenck HJ. Crime and Personality. London: Routledge/Kegan Paul; 1991.

2. Derogatis LR. Symptom Checklist-90-R: Administration, Scoring and Procedures Manual. San Antonio, TX: Pearson Clinical Assessment; 1994.

3. Hare RD. Psychopathy Checklist - Revised: Technical Manual. North Tonawanda, NY: Multi-Health Systems; 2003.

4. Hayes JM, O'Reilly G. Psychiatric disorder, IQ, and emotional intelligence among adolescent detainees: a comparative study. Legal Criminol Psychol. 2013;18:30-47.

5. Zara G, Farrington DP. A longitudinal analysis of early risk factors for adult-onset offending: what predicts a delayed criminal career. Crim Behav Ment Health. 2010;20(4):257-273.

6. Hill G. AS and A Level Psychology through Diagrams. Oxford: Oxford University Press; 2009.

7. Leschied A, Chiodo D, Nowicki E, Rodger S. Childhood predictors of adulthood criminality: a meta-analysis drawn from the prospective longitudinal literature. Can J Criminol Crim Justice. 2008;50(4):435-465.

8. Kosten PA, Scheier LM, Grenard JL. Latent class analysis of peer conformity: who is yielding to pressure and why? Youth Soc. 2012;45(4):565-590.

9. Vogel M, Barton MS. Impulsivity, school context, and school misconduct. Youth Soc. 2011;45(4):455-479.
10. Farrington DP. Key Results from the First Forty Years of the Cambridge Study in Delinquent Development. 1991. Available from: http://ink. springer.com/chapter/10.1007\%2F0-306-47945-1_5.

11. Farrington DP, Coid J, Harnett L, et al. Criminal Careers and Life Success: New Findings from the Cambridge Study in Delinquent Development. London: Home Office Findings 281; 2006.

12. Johnson JG, Smailes E, Cohen P, Kasen S, Brook JS. Anti-social parental behavior, problematic parenting and aggressive offspring behavior during adulthood: a 25-year longitudinal investigation. Br J Criminol. 2004;44(6):915-930.

13. Walters GD. How many factors are there on the psychological inventory of criminal thinking styles (PICTS)? Crim Behav Ment Health. 2005;15(4):273-283.

14. Maniadaki K, Kakouros E. Social and mental health profiles of young male offenders in detention in Greece. Crim Behav Ment Health. 2008;18(4):207-215.

15. Farrington DP, Ttofi MM. Violence as a predictor of offending, violence and later life outcomes. Crim Behav Ment Health. 2011;21(2):90-98.

16. Mundia L, Bakar HAZBA. The suitability of the EPQ-R short scale for counseling Brunei student teachers when administered in English and Malay languages. Compare. 2010;40(5):641-658.

17. Mundia L. Social desirability, non-response bias and reliability in a long self-report measure: illustrations from the MMPI-2 administered to Brunei student teachers. Educ Psychol. 2011;31(2):207-224.

18. Yusuf NM, Mundia L. The status of counseling in Brunei prisons: qualitative exploratory case study. $J$ Sociol Res. 2014;5(1):24-39.

19. Mundia L, Matzin R, Mahalle S, Hamid MHS, Osman RS. Youth and Adult Crimes in Brunei Darussalam: Short Survey and Psychological Report of Insights from a Prison Sample. Bandar Seri Begawan: Sultan Hassanal Bolkiah Institute of Education, Universiti Brunei Darussalam; 2013.

20. Mundia L [webpage on the Internet]. Prevalence of depression, anxiety and stress in Brunei student teachers. Internet J Ment Health. 2010;6(2). Available from: http://www.ispub.com/journal/the_internet_journal_of_mental_health.html. Accessed April 5, 2016.

21. Mundia L. Relationship between mental health and teaching: evidence from Brunei trainee teachers. Int J Ment Health. 2013;42(2-3):73-98.

22. Landau S, Everitt BS. A Handbook of Statistical Analyses Using SPSS. Washington, DC: Chapman \& Hall; 2004.

23. Der G, Everitt BS. A Handbook of Statistical Analyses Using SAS. New York: Chapman \& Hall; 2002

24. Shaffer DR. Developmental Psychology: Childhood and Adolescence. 6th ed. Belmont: Wadsworth/Thomson Learning; 2002.

25. Utting G. Reducing Criminality among Young People: A Sample of Relevant Programs in the United Kingdom. Home Office Research Study No. 161. London: HMSO; 1996.

26. Harrower J. Psychology in Practice: Crime. Abingdon: Hodder \& Stoughton; 2001.

27. Meichenbaum D. Cognitive Behavior Modification: An Integrative Approach. New York: Plenum; 1977.

28. Farrington DP. Understanding and Preventing Youth Crime. New York: Joseph Rowntree Foundation; 1996
Psychology Research and Behavior Management

\section{Publish your work in this journal}

Psychology Research and Behavior Management is an international, peerreviewed, open access journal focusing on the science of psychology and its application in behavior management to develop improved outcomes in the clinical, educational, sports and business arenas. Specific topics covered in the journal include: Neuroscience, memory and decision making; Behavior

\section{Dovepress}

modification and management; Clinical applications; Business and sports performance management; Social and developmental studies; Animal studies. The manuscript management system is completely online and includes a very quick and fair peer-review system, which is all easy to use. Visit http://www. dovepress.com/testimonials.php to read real quotes from published authors. 